\title{
The Global Crisis and the Answer of Economics ${ }^{a}$
}

\author{
GebHard KirChGäSSNER ${ }^{\text {b }}$
}

Our annual meeting with its topic "Globalisation: Patterns and Challenges" is taking place in a period of big challenges for us: for economic policy, but also for Economics as a social science. We are experiencing the most severe economic downturn since the Great Depression eighty years ago. None of us expected this development one year ago; we all expected somewhat reduced but still positive economic growth rates for this year and the next. The general public has blamed us for failing to foresee this development. Consequently, there is not only an economic crisis; we can also perceive a considerable reduction in the public reputation of our profession, and, as is claimed at least by many people, a crisis of Economics as a science as well.

This is connected with the topic of our meeting in two ways. First, globalisation is not a cause of the crisis, but the globalisation of financial markets was a necessary condition for the immense dimension of the crisis. Without it, the crisis in the U.S. subprime market might have led to a crisis of the U.S. financial system, but European banks might only have been affected indirectly, at most. Second, periods of crises are usually also periods of increasing protectionism. At the moment, there are hardly any indications of hard protectionism. Treaties and/ or memberships of international organisations like the World Trade Organisation (WTO) or the European Union, prevent this at least to a large extent. There are, however, indications of soft protectionism, if, for example, citizens of the United States or France are requested to "Buy American" or "Buy French". Globalisation cannot be totally reversed, of course, but history tells us that trade liberalisations can be reversed. If this were the case to any great extent, Switzerland with its largely internationally oriented economy would be one of the main losers.

As a scientific society primarily specialised in dealing with economic problems, we have to endure the question as to why we have not been able to foresee this crisis and, in doing so, to assist in preventing it or, at least, mitigating its negative consequences. What were our mistakes, and what is our responsibility for this crisis? This question, as well as the answer to it, are of high societal relevance.

\footnotetext{
a Presidential Opening Statement for the Annual Meeting of the Swiss Society of Economics and Statistics, Geneva, 26 June 2009.

b University of St. Gallen, SIAW-HSG, Bodanstrasse 8, CH-9000 St. Gallen.
} 
First, as a result of this crisis, millions of people will lose their jobs, and some of them will never find a job again. Second, recent decades have seen an unprecedented triumphal procession of economic ideas. The privatisation of activities performed in earlier times by government agencies, as well as the deregulation of markets that were heavily regulated before, have considerably changed the world since the seventies. Of course, we have often not been satisfied with what the government did; many of us demanded even more privatisation and deregulation. In Germany, there is, for example, a private but rather influential circle of right-wing liberal professors who more or less regularly published statements demanding (even) "more market" for rather different sectors of our society. There is no other social science that has had a similarly far-reaching influence on the development of our society during recent decades.

But what were our mistakes? We might certainly be blamed for underestimating the importance of the government for a prosperous economic development. Traditional Public Finance pointed to "market failure" in various areas. These failures have been interpreted as justifications for government interventions, with goods or services being produced in the public sector, for instance, or with some sectors of the economy being heavily regulated. The more recent development of Public Choice rightly pointed to the fact that governments are not benevolent dictators but have their own political objectives. Thus, there is also "government failure". Many even believed that only the latter is relevant. Thus, in their opinion, nearly everything could and should be done by markets. This turned out to be a serious fallacy.

Privatisation and deregulation were undertaken with the promise of better and/or cheaper provision for consumers. In many cases but not in all, this actually happened. On the other hand, the current crisis shows that deregulation might incorporate risks that are hardly expected. And, what is even more astonishing, nearly everybody relies on the government in this crisis. What counts is not only the fact that Keynesian recipes are acceptable again after a period when they seemed to have been written off. More surprising is the fact that governments intervene with billions of Swiss Francs, Euros, or Dollars, respectively, in the financial markets in order to prevent a general economic crash. But those are the very markets that have been said to be the most efficient ones, at least according to our theory; they process new information immediately and are, therefore, nearly always in equilibrium. If we follow the theory of efficient markets, those are the markets that should hardly produce any reason for government interventions.

Sometimes it is stated that the true cause of the whole crisis is (almost) exclusively government failure. The U.S. government insisted on making home 
ownership possible for as many citizens as possible. And the extremely low mortgage interest rates that were supposed to enable this were a consequence of the policy of the Federal Reserve and its former president, Alan Greenspan.

Alan Greenspan conceded that his policy was partly a mistake. ${ }^{1}$ But this perception of the cause of the crisis is, nevertheless, too feeble and, also, not correct. It is too feeble insofar as nearly all of us applauded Alan GreEnsPan when he managed to prevent a threatening worldwide recession after the terror attacks of September 11, 2001, by implementing his low-interest monetary policy. In hindsight we know, of course, that it would have been better to raise interest rates again earlier in order to prevent a bursting bubble in the U.S. mortgage market. But who demanded this several years ago? There were only very few warning voices, and the economic profession hardly noticed them and did not take them seriously into account, either.

Moreover, such a perception of the cause of the crisis is also wrong because it supposes a mono-causality that does not exist. Low interest rates in the United States were not a sufficient reason to induce people to take up mortgages when it was obvious that they would be unable to bear the burden of these mortgages in the long run, nor that low-ranked mortgages were structured in such a way that hardly anybody was able to assess the risks of these papers, nor that foreign banks like UBS heavily invested in this market. Thus the U.S. Federal Reserve bears only part of the responsibility, no more.

Financial economists are also partly responsible. They offered instruments to evaluate the risks of security papers that, as we know today, were not appropriate. The empirical estimates were based on data from periods of low volatility and, therefore, underestimated the risk. It is a pressing and important task of Financial Economics to develop models that are better suited to evaluate the risk of such papers and, in addition, to propose regulations that, on the one hand, reduce the probability that such a crisis will happen again and, on the other hand, do not obstruct innovations in the financial markets overmuch.

Moreover, we should also establish a better balance between the financial sector and the rest of our economy again. The financial sector and the value created there is, of course, very important for Switzerland, not least because of the income and the tax revenue created there. But ultimately, this sector has an auxiliary function in the economy; its task is to ensure that capital is channelled towards its

1 See for this E.L. Andrews, Greenspan Concedes Error on Regulation, New York Times vom 23. Oktober 2008. (http://www.nytimes.com/2008/10/24/business/economy/24panel.html $(11 / 06 / 09)$. 
most productive uses. However, those innovations that are of the greatest importance for the well-being of the people as well as for economic growth only happen to a very small part in the finance industry. In this respect, the most important sectors are those where goods and services are produced that are demanded by the citizens for their own sake, or because they allow consumers to receive benefits from services generated by these goods. In these sectors, technical progress allows for permanent quantitative and, what is even more important, qualitative increases in production. It is not for nothing that DARON ACEMOGLU states that "highly skilled labour should be reallocated away from the financial industry towards more innovative sectors." ${ }^{2}$ This probably holds for Switzerland as well.

In the German-speaking countries, the crisis and the malfunctioning of mathematical models in Financial Economics in particular gave reason for a fundamental criticism of modern Economics, heavily influenced by developments in the Anglo-Saxon countries. A return to national traditions, sometimes to the German Historical School, but more often to Ordo-Liberalism, has been called for. In an editorial of the business section in the $N Z Z$ daily newspaper, modern economics was recently denoted as "Dismal Economics". ${ }^{3}$ Ordo-Liberalism has its merits, of course, especially with respect to the German economic order after World War II. However, the basic ideas of Ordo-Liberalism have been taken up by modern Constitutional Economics and also at least partly in the political philosophy of John RawLs. Thus invoking Ordo-Liberalism as a reason for uncoupling economics from the international scientific development is rather strange. Not only the economy, but also Economics, is globalised today. Any separation from international developments nearly always results in marginalisation. This is no argument against (international) competition between different approaches in Economics, but a strong one against self-contained national paths.

If we, as the Swiss Society of Economics and Statistics, intend to draw conclusions from the current situation, the following seems to be obvious to me:

(i) We have to accept our share of responsibility for the current economic situation. First of all, this implies that we deliberate once again about the appropriate role of the state with regard to economic development. Hardly any of

2 D. Acemoglu (2009), The Crisis of 2008: Structural Lessons For and From Economics, Centre for Economic Policy Research Policy Insight No. 28, London, January 2009 (http://www. cepr.org/pubs/ PolicyInsights/PolicyInsight28.pdf (19/05/05)).

3 G. Schwarz, Die trostlose Wirtschaftswissenschaft, Neue Zürcher Zeitung Nr. 84 vom 11./12. April 2009, p. 19. 
us will accept the current enormous impact in the long-run, but a return to the situation as it was before the outbreak of the crisis in 2007 is also hardly conceivable.

(ii) To accept our share of responsibility also entails making useful and feasible proposals as to how such crises can be prevented in the future or, at least, how their social consequences can be mitigated. Thus we need new, not necessarily more, but better or more appropriate regulations for the financial sector. But we also need rules in order to prevent banks from becoming "too big to fail", either by preventing them from becoming too big or by means of rules which ensure that even banks as big as the UBS can go bankrupt without the catastrophic systemic consequences we are afraid of today.

(iii) However, the fact that we will have to rethink several aspects of our economic systems and that we will have to set new rules in some areas does not mean that we should forget everything we have learned from our science. In the current situation, two points are particularly important. First, given today's necessary concentration on the short-term, business-cycle aspects of the economy, we should also take into account the long-term, growth aspects of our policy measures. Any flash in the pan that dies down rapidly but creates future burdens, is useless. Second, it is important, particularly for a small open economy like the Swiss one, that we keep the international markets open and resist protectionism.

Thus we are back to the topic of our annual meeting: globalisation. So far, and all things considered, Switzerland with its very open economy did indeed benefit from this development, and we should do everything to ensure that this will also hold in the future. In this respect, our topic is very appropriate, given the current economic situation. I hope that you will all benefit from this annual meeting. 